\title{
JUURNAL.RU
}

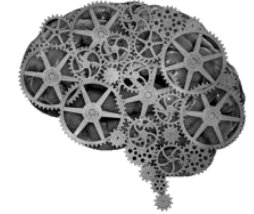

COMPANY GROUP "INTELLEKT"

Кузьмина Т.В. Ульяновское гвардейское суворовское военное училище

Ульяновск, Россия

doi: 10.18411/lj2016-3-19

\section{Педагогические аспекты формирования межкультурной компетенции обучающихся на уроках иностранного языка}

В законе РФ « Об образовании», в национальной доктрине образования Российской Федерации до 2020 года, в Федеральном государственном стандарте среднего (полного) общего образования второго поколения определены и раскрыты основные принципы образовательной политики в России, направленной на внедрение в мировое образовательное пространство, расширение масштабов межкультурного взаимодействия, формирование профессиональной элиты[6]. В связи с этим, в качестве одной из ключевых задач современной российской школы выдвигается задача подготовки обучающихся к культурному, профессиональному и личному общению с представителями разных стран и культур.

В этом плане большим образовательным, воспитательным и развивающим потенциалом обладает иностранный язык. Основное направление в методике преподавания иностранного языка - формирование межкультурной коммуникативной компетенции, обеспечивающей практическое владение иностранным языком и общение с носителями изучаемого языка. Именно коммуникативный метод ориентируется на личность ученика, позволяет учитывать сущность языка как орудия деятельности человека, средство становления личности, позволяет теснее связывать учебный процесс с 
жизненными запросами и ориентациями учащихся[5]. Следовательно, вопрос о межкультурном аспекте в обучении иностранному языку наиболее актуален сегодня для преподавателей иностранного языка: при обучении обучающихся иностранному языку необходимо создать условия для их самосовершенствования как равноправных партнеров по межкультурной коммуникации, сформировать определенный уровень социокультурных знаний и умений. В этой связи цель обучения иностранному языку может быть уточнена и определена следующим образом: развитие способностей обучающихся использовать иностранный язык как инструмент познания, приобщения и адаптации к новому социальному опыту, как средство эффективного решения коммуникативных задач в сферах личных, профессиональных и социальных интересов[2].

Присвоение социокультурных знаний, способствующих формированию межкультурной компетенции осуществляется обучающимися в ходе лекций, бесед - с использованием преподавателем метода персонифицированного изложения материала, метода биографической рефлексии, методов проблемного и коммуникативного обучения. Лекция-беседа по культуроведческим темам носит диалоговый характер и позволяет актуализировать имеющиеся знания и активизировать самостоятельную работу обучающихся. При проведении лекции-беседы преподаватель ставит ключевые вопросы, которые решаются в ходе диалога с обучающимися. На кино-лекции обучающимся предлагаются к обсуждению сюжеты из английских видеофильмов. Использование видеоролика, клипа, мультфильма в формировании межкультурной компетенции обучающихся в учебном процессе создаёт естественный, увлекательный, знакомый фон для включения любого содержательного и языкового материала, придаёт игровой характер обычным учебным действиям, а главное активизирует их мыслительный процесс. Такие упражнения можно использовать и как форму скрытого контроля знаний и умений обучающихся как по одной теме, так и по блоку тем[4]. 
Формирование умений и навыков межкультурной коммуникации, a, следовательно, и самой межкультурной компетенции осуществляется на занятиях, проводимых в форме дискуссий, конкурсов, театральных постановок по культуроведческой тематике, заочного путешествия по странам изучаемого языка, непосредственных встреч с представителями иноязычных культур посредством метода моделируемых ситуаций, метода ролевых игр, метода проектов и творческих заданий, метода самоописания, содержащего анализ процесса самоосознания и осмысления своих внутренних состояний в процессе взаимодействия с представителями иноязычных культур, осмысления своих способностей и потребностей в достижении поставленной цели.

В процессе подготовки обучающихся к межкультурной коммуникации осуществляется их продвижение к обретению своей целостности: осознанию своего «Я» и себя как равноправного партнера по данному взаимодействию, к определению основных перспектив и планов межкультурной коммуникации. Основными условиями обретения целостности являются погружение в свой внутренний мир, пробуждение интереса к нему, формирование умения работать с собственным сознанием и самосознанием, расширение внутреннего духовного опыта в процессе взаимодействия с родной и иноязычной культурой. Для выполнения вышеназванных условий необходимо использовать такие виды работ с самосознанием, как: общекультурные тренинги (которые помогают осознавать себя представителем конкретной культуры), самовнушение, релаксация, внутренний диалог, самотестирование, работа в малых группах, где происходит обсуждение результатов, осуществляется помощь в осознании себя и совместная оценка результата работы в процессе групповой рефлексии. В качестве упражнения по самовнушению можно использовать «Волшебное слово» - секрет мгновенной коррекции отношения к чему-либо или к кому-либо. Данное слово напоминает ученику об успешном событии в прошлом и, таким образом, помогает ему приобрести позитивное настроение и корректирует его отношения с партнером по общению. 
Для того, чтобы обучающиеся могли больше узнать друг о друге, стать ближе друг к другу с ними выполняются такие упражнения, как: «Я тебя знаю», «Поговорим!», «Интервью», «Учимся понимать друг друга». Упражнение «Поговорим!» направлено на обучение учащихся вести беседу по заданной теме культуроведческого направления без подготовки. Все обучающиеся садятся в круг и, передавая друг другу мяч, высказываются по предложенной теме в течение минуты. В упражнениях «Я тебя знаю», «Интервью», «Учимся понимать друг друга» учащиеся фантазируют и учатся задавать и отвечать на вопросы друзей по переписке и стран изучаемого языка с целью обмена информацией об истории, культурных традициях, достопримечательностях своих стран. Все вышеназванные упражнения способствуют осознанию себя представителем конкретной культуры и равноправным партнером по межкультурной коммуникации.

Обучающие игры на уроках иностранного языка способствуют развитию познавательной активности у обучающихся, формируют умения учебного сотрудничества. Приведем примеры некоторых обучающих игр:

Симпозиум - представляется страноведческий материал на английском языке (текст), который необходимо внимательно прочитать в течение определенного отрезка времени, распределить роли: редактор, критик, автор, рецензент, незнайка, доцент, академик и другие (по дополнению обучающихся). Затем каждый в своем амплуа должен изложить учебный текст. Остальные участники симпозиума оценивают выступления. Выигрывает самый оригинальный выступающий, наиболее интересно изложивший учебный текст. Участники симпозиума имеют право добавить и дополнить выступления друг друга.

Необычный доклад - читается культуроведческий текст на английском языке, потом передается содержание этого текста при помощи знаков, схем, рисунков соседу справа и каждый делает доклад по данному тексту, используя рисунки или схемы своего соседа. 
Но наиболее эффективным приемом организации межкультурной коммуникации и формирования межкультурной компетенции обучающихся являются их непосредственные встречи с представителями других культур (туристические поездки, приглашение зарубежных гостей): во-первых, пограничные ситуации погружают обучающихся в особый мир - равенства, открытости, взаимопонимания, взаимопомощи, во-вторых, поездки и приглашения зарубежных гостей позволяют организовать встречу культур в ситуации лицом к лицу. Зарубежные гости могут рассказать о своей стране, о своей школе или о своем университете, поделиться своими впечатлениями о пребывании в России, а обучающиеся могут задать интересующие их вопросы.

Именно в таких контактах учащиеся переживают отличие, особенность другого - и это очень важно. Они общаются с людьми - носителями иного культурного опыта, иных духовных ценностей, иных стереотипов поведения. Знакомство с иным образом жизни еще более укрепляет чувство патриотизма к своей культуре и историческим ценностям. 


\section{Литература:}

1. Концепция долгосрочного социально-экономического развития России до 2020г. [Текст] //Официальные документы в образовании. - ООО Фирма «Частное образование».- 2008г.- №135.

2. Мангутова, О. Н. Современный урок иностранного языка: основные подходы к проектированию [Текст] / О. Н. Мангутова // Интернет-журнал "Эйдос". - 2010 / http://eidos.ru; e-mail: info@eidos.ru.

3. Миролюбов, А. А. Культуроведческая направленность в обучении иностранным языкам [Текст] /А.А. Миролюбов// Иностранные языки в школе.-2001.- № 5.- С. 11-13.

4. Сафонова, В. П. Современный урок иностранного языка [Текст] / В. П. Сафонова. - М.: Учитель, 2011.

5. Соловова, Е. Н. Методика обучения иностранным языкам. [Текст]: базовый курс лекций / Е.Н.Соловова. - М.: Просвещение, 2005.

6. Федеральный государственный стандарт основного общего образования [Текст] / Министерство образования и науки РФ. - М.: Просвещение, 2010. $-32 \mathrm{c}$. 